\title{
Structural and Electrical Transport Properties of CdS and Al-doped CdS Thin Films Deposited by Spray Pyrolysis
}

\author{
A. Hasnat ${ }^{1}$ and J. Podder ${ }^{2 *}$ \\ ${ }^{1}$ Department of Physics, Jagannath University, Dhaka-1100, Bangladesh \\ ${ }^{2}$ Department of Physics, Bangladesh University of Engineering and Technology, Dhaka-1000, \\ Bangladesh
}

Received 3 September 2011, accepted in final revised form 22 November 2011

\begin{abstract}
Cadmium sulfide (CdS) and aluminum (Al) doped cadmium sulfide $\left(\mathrm{Cd}_{1-\mathrm{x}} \mathrm{Al}_{\mathrm{x}} \mathrm{S}\right)$ thin films have been deposited on glass substrate at $300{ }^{\circ} \mathrm{C}$ by spray pyrolysis. The structural and electrical properties of the as-deposited films have been characterized using Energy Dispersive X-ray (EDX) analysis, X-ray diffraction (XRD) and D.C. electrical measurement. The effect of $\mathrm{Al}$ on the surface morphology of CdS film was studied by Scanning Electron microscopy (SEM). EDX shows that the deposited samples are stoichiometric. The peak intensities observed in the XRD patterns were found consistent to a polycrystalline hexagonal structure. The XRD study shows that the hexagonal structure of CdS is not much affected with respect to Al doping. Al-doped CdS thin films show low electrical resistivity of about $48 \Omega \mathrm{cm}$ and high carrier density of about $1.1 \times 10^{19} \mathrm{~cm}^{-3}$.
\end{abstract}

Keywords: Spray pyrolysis; CdS, $\mathrm{Cd}_{1-\mathrm{x}} \mathrm{Al}_{\mathrm{x}} \mathrm{S}$; Thin films; EDX; XRD; Hall mobility.

(c) 2012 JSR Publications. ISSN: 2070-0237 (Print); 2070-0245 (Online). All rights reserved. doi:10.3329/jsr.v4i1.8548 J. Sci. Res. 4 (1), 11-19 (2012)

\section{Introduction}

The II-VI compound semiconductors are of great importance due to their applications in various electro-optic devices. Cadmium sulphide (CdS) is a wide band gap semiconductor belonging to II-VI group compounds [1-3]. In recent years, much effort has been given on CdS semiconductors for making p-n heterojunction thin solar cells. The addition of trace amount of transition metal ion into CdS host plays an important role in modifying the structural, optical and electrical transport properties of the binary alloy material [4-10]. Metal chalcogenides are attracting a great deal of attention because of their many fold importance in a wide spectrum of optoelectronics devices [11-14]. Ternary chalcogenide

*Corresponding author: jpodder@phy.buet.ac.bd 


\section{Structural and Electrical}

systems are known to have well defined band structure in which the energy gap vary continuously with composition in the constituent compounds [15-16]. Such materials allow the possibility of tailoring their properties to meet specific requirements. The doping of group III elements has been found to decrease the resistivity of CdS thin films. The effect of $\mathrm{Al}$ incorporation on the structural and electrical properties of CdS has been investigated to determine the feasibility of $\mathrm{CdS}$ films for the potential technological application. From that interesting point of view, $\mathrm{Al}$ is selected as dopant from group III. In this paper, the structural and electrical properties of CdS doping with various concentrations of $\mathrm{Al}$ have been studied in details.

\section{Experimental Details}

AR grade cadmium acetate $\mathrm{Cd}\left(\mathrm{COOCH}_{3}\right)_{2}$, thiourea $\left(\mathrm{NH}_{2} \mathrm{CSNH}_{2}\right)$ and aluminum acetate $\left(\mathrm{Al}\left(\mathrm{CH}_{3} \mathrm{COO}\right)_{3} \cdot 2 \mathrm{H}_{2} \mathrm{O}\right)$ were used as precursors for the source of $\mathrm{Cd}, \mathrm{S}$ and Al. All the chemical of Merck brand, Germany, were used. Aqueous solution of (0.1 M) cadmium acetate, $(0.2 \mathrm{M})$ of thiourea $\left(\mathrm{NH}_{2} \mathrm{CSNH}_{2}\right)$ were taken for CdS thin film and $(0.1 \mathrm{M})$ of cadmium acetate, $0.1 \mathrm{M}$ aluminum acetate, $(0.2 \mathrm{M})$ thiourea were taken for doping of $\mathrm{Al}$ into CdS i.e. $\mathrm{Cd}_{1-\mathrm{x}} \mathrm{Al}_{\mathrm{x}} \mathrm{S},(x=0,0.05,0.10,0.15,0.20,0.40,0.60,0.80,1.00)$ thin film preparation. Ethanol was used as the reducing agent in the present work. The CdS and $\mathrm{Cd}_{1-\mathrm{x}} \mathrm{Al}_{\mathrm{X}} \mathrm{S}$ thin films were prepared by spraying the solution onto a heated glass substrates kept at around $300{ }^{\circ} \mathrm{C}$. In this technique, the chemicals vaporized and react on the substrate surface after reaching on it. Al doped CdS thin films were deposited on glass substrate. The possible chemical reaction that takes place on the heated substrate to produce $\mathrm{Cd}_{1-\mathrm{x}} \mathrm{Al}_{\mathrm{x}} \mathrm{S}$ may be as follows:

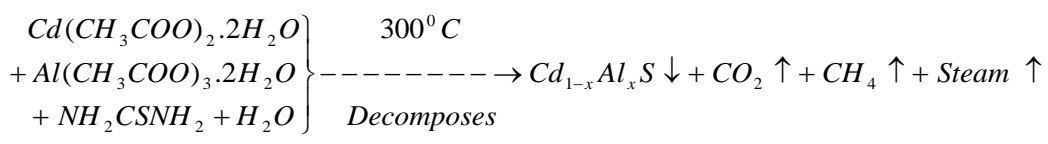

\section{Results and Discussion}

\subsection{Surface morphology}

Pure CdS and Al-doped CdS films of various compositions are found more or less smooth, compact, continuous and uniform. SEM images show that $\mathrm{Al}$ doping does not have significant effect on the surface morphology of the CdS thin film. There are some spheroid shape growth appears as the creation of nucleation centre on the film surface. These shapes are more visible in Figs. 1 (b) and 1(c). These are most probably aggregated due to colloidal particles formed in solution and then absorbed on the film. 

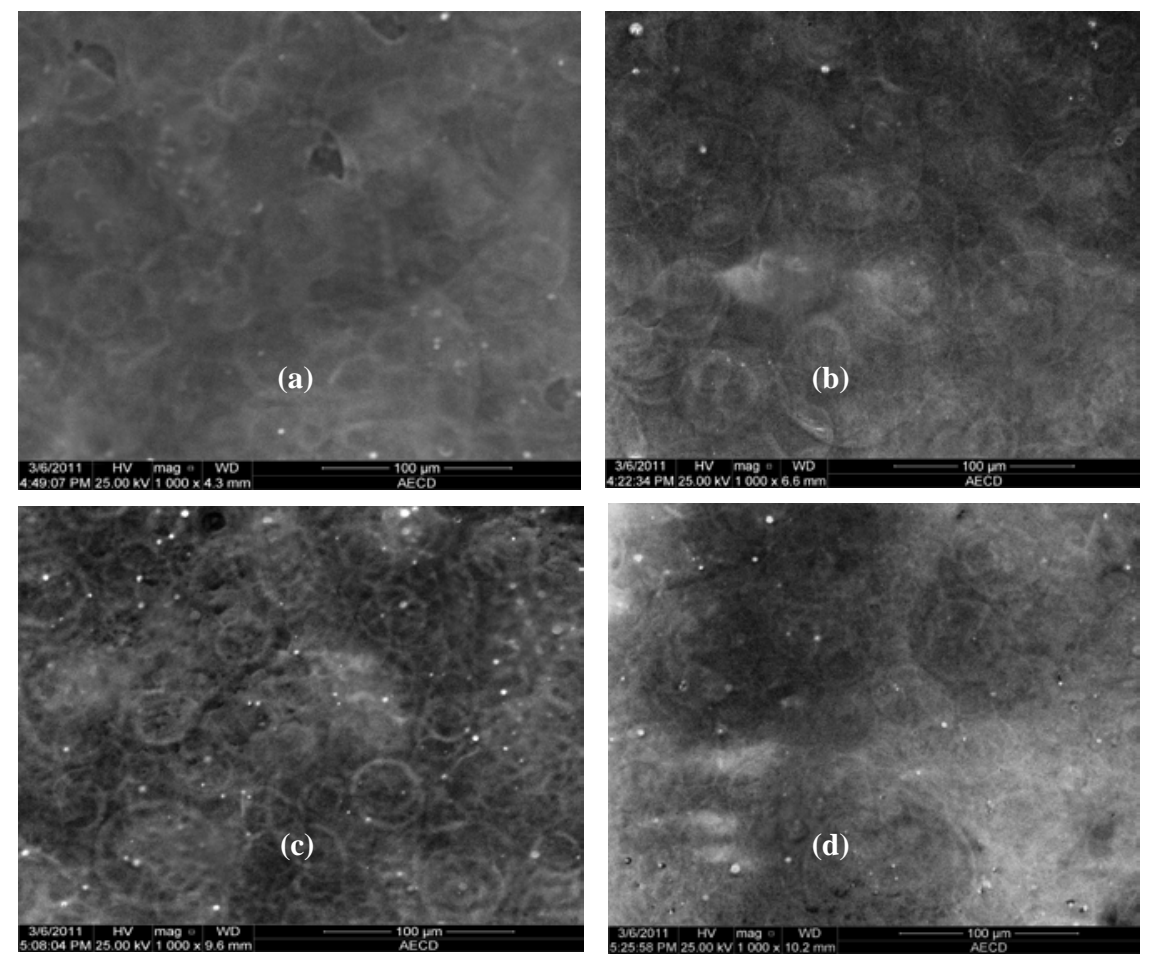

Fig. 1. SEM micrograph of $\mathrm{Cd}_{1-\mathrm{x}} \mathrm{Al}_{\mathrm{x}} \mathrm{S}$ film for (a) $x=0$, (b) $x=0.01$, (c) $x=0.03$ and (d) $x=0.06$.

\subsection{Compositional studies}

During the deposition of $\mathrm{CdS}$ thin film doped with $\mathrm{Al}, \mathrm{Al}$ was incorporated with various concentrations. Hence $\mathrm{Cd}$ is substituted by $\mathrm{Al}$ in the films. Table 1 shows the composition of the elements of the solution to deposit the thin films. Tables 2 and 3 show quantitative results of pure $\mathrm{CdS}$ and $\mathrm{Al}(\mathrm{x}=0.01)$ doped $\mathrm{CdS}$ thin films respectively from EDX analysis. Fig. 2 shows the EDX spectra of (a) Pure CdS and (b) Al doped CdS thin films. Sulphur deficiency was observed in all the films. This may be due to the fact that sulphur has great affinity towards oxygen, so it might have converted to $\mathrm{SO}_{2}$ and then evaporated. A strong peak is observed which corresponds to Si due to substrate. At high operating voltage the electron beam penetrates the film and reaches the glass surface, which results the Si peak. Two different peaks corresponding to $\mathrm{Cd}$ and S are found in the spectrum, which confirms the CdS thin film. For different concentrations of $\mathrm{Al}$ in the solution, there is also $\mathrm{Al}$ peak in the spectra. EDX result reveals that the deposited films are very close to the nominal composition. 


\section{Structural and Electrical}

Table 1 . Atomic \% of different compositions of $\mathrm{Cd}_{1-\mathrm{x}} \mathrm{Al}_{\mathrm{x}} \mathrm{S}$ matrix.

\begin{tabular}{cccccc}
\hline \multirow{2}{*}{ Compositions } & \multicolumn{2}{c}{$\mathrm{Cd}+\mathrm{Al}(0.1 \mathrm{M})$} & \multirow{\mathrm{Al}}{*}{$/[\mathrm{CdS}]$} & $\begin{array}{c}\mathrm{S}(0.1 \mathrm{M}) \\
\text { atomic } \%\end{array}$ & Total $(0.1 \mathrm{M})$ \\
\cline { 2 - 3 } $\mathrm{CdS}$ & 50 & 00 & 00 & 50 & 100 \\
$\mathrm{Cd}_{0.99} \mathrm{Al}_{0.01} \mathrm{~S}$ & 49 & 1 & 0.010 & 50 & 100 \\
$\mathrm{Cd}_{0.97} \mathrm{Al}_{0.03} \mathrm{~S}$ & 47 & 3 & 0.030 & 50 & 100 \\
$\mathrm{Cd}_{0.94} \mathrm{Al}_{0.06} \mathrm{~S}$ & 44 & 6 & 0.064 & 50 & 100 \\
$\mathrm{Cd}_{0.91} \mathrm{Al}_{0.09} \mathrm{~S}$ & 41 & 9 & 0.098 & 50 & 100 \\
$\mathrm{Cd}_{0.88} \mathrm{Al}_{0.12} \mathrm{~S}$ & 38 & 12 & 0.136 & 50 & 100 \\
$\mathrm{Cd}_{0.85} \mathrm{Al}_{0.15} \mathrm{~S}$ & 35 & 15 & 0.176 & 50 & 100 \\
$\mathrm{Cd}_{0.82} \mathrm{Al}_{0.18} \mathrm{~S}$ & 32 & 18 & 0.219 & 50 & 100 \\
\hline
\end{tabular}
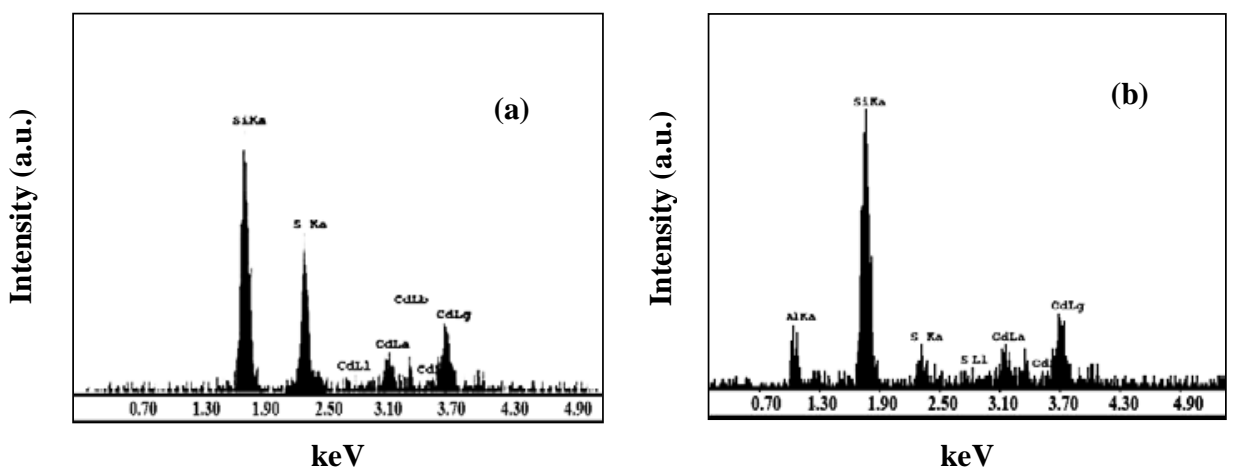

Fig. 2. EDX micrograph of (a) pure $\mathrm{CdS}$ and (b) $\mathrm{Al}$ doped cadmium sulfide $\left(\mathrm{Cd}_{1-\mathrm{x}} \mathrm{Al}_{\mathrm{x}} \mathrm{S}\right)$ thin films for $x=0.01$ on glass substrate.

Table 2. Quantitative results of pure CdS thin films from EDX analysis.

\begin{tabular}{cccc}
\hline Element & $\mathrm{Wt} \%$ & $\mathrm{At} \%$ & {$[\mathrm{Cd}] /[\mathrm{S}]$} \\
\hline $\mathrm{Si}$ & 44.47 & 45.82 & \\
$\mathrm{~S}$ & 32.49 & 25.88 & 1.09 \\
$\mathrm{Cd}$ & 23.04 & 28.30 & \\
\hline \multicolumn{5}{c}{} & 100 & 100 & \\
\hline
\end{tabular}


Table 3. Quantitative results of $\mathrm{Cd}_{1-\mathrm{x}} \mathrm{Al}_{\mathrm{x}} \mathrm{S}$ thin films for $\mathrm{x}=0.01$.

\begin{tabular}{cccc}
\hline Element & Wt\% & At\% & {$[\mathrm{Al}] /[\mathrm{CdS}]$} \\
\hline $\mathrm{Si}$ & 44.66 & 45.93 & \\
$\mathrm{~S}$ & 31.48 & 25.19 & 0.018 \\
$\mathrm{Cd}$ & 22.91 & 27.92 & \\
$\mathrm{Al}$ & 0.95 & 0.96 & \\
\hline & 100 & 100 & \\
\hline
\end{tabular}

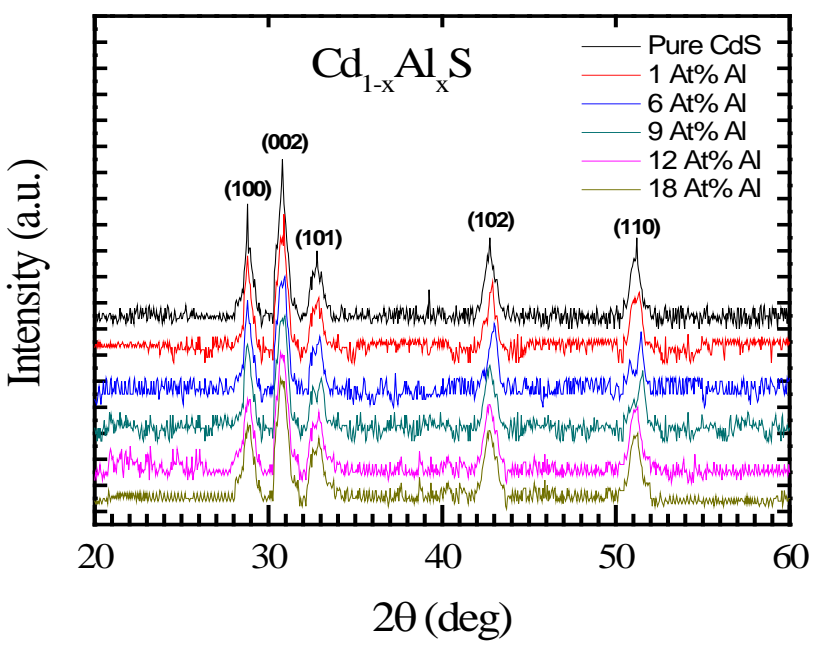

Fig. 3. XRD spectra of $\mathrm{Cd}_{1-\mathrm{x}} \mathrm{Al}_{\mathrm{X}} \mathrm{S}$ thin films.

\subsection{Structural studies}

The X-ray diffraction patterns are shown in Fig. 3. No change in the characteristic peak positions was observed in samples doped with Al. This means that the doped CdS samples retain the hexagonal structure. The degree of crystallinity for CdS samples decreases gradually by increasing the concentration of the Al. Grain size of the film was determined from the strongest peak (002) of XRD patterns using Scherrer formula,

$$
D_{g}=\frac{0.9 \lambda}{\Delta \cos \theta}
$$

where $D_{\mathrm{g}}$ is the average grain size, $\lambda$ is the wavelength of the radiation used as the primary beam of $\operatorname{CoK}_{\alpha}(\lambda=1.791 \AA), \theta$ is the angle of incidence in degree and $\Delta$ is the full width at half maximum (FWHM) of the peak in radian, which was determined experimentally after 


\section{Structural and Electrical}

correction of instrumental broadening (in the present case it is $0.05^{\circ}$ ). Average grain size of thin film was determined in the range of 22.23 to $28.93 \mathrm{~nm}$, which indicates the nanometric size of $\mathrm{Cd}_{1-\mathrm{x}} \mathrm{Al}_{\mathrm{x}} \mathrm{S}$ grains developed in the film. The $d$-values and lattice constants are shown in the Table 4 and Table 5, respectively.

Table 4. The $d_{\text {hkl }}$ values of sample $\mathrm{Cd}_{1-\mathrm{x}} \mathrm{Al}_{\mathrm{x}} \mathrm{S}$ for (002) plane.

\begin{tabular}{cccccc}
\hline Compositions & $\begin{array}{c}2 \theta \\
\text { (degree) }\end{array}$ & $d_{\text {hkl }}(\AA)$ expt & $\begin{array}{c}d_{\text {hkl }}(\AA) \\
\text { (from JCPD) }\end{array}$ & $\begin{array}{c}\text { Standard Miller } \\
\text { Indices (hkl) }\end{array}$ & $\begin{array}{c}\text { Grain size }(\xi) \\
(\mathrm{nm})\end{array}$ \\
\hline $\mathrm{Cd}_{1.00} \mathrm{Al}_{0.00} \mathrm{~S}$ & 30.82 & 3.3688 & 3.361 & $(002)$ & 22 \\
$\mathrm{Cd}_{0.99} \mathrm{Al}_{0.01} \mathrm{~S}$ & 30.91 & 3.3601 & 3.357 & $(002)$ & 25 \\
$\mathrm{Cd}_{0.94} \mathrm{Al}_{0.06} \mathrm{~S}$ & 30.94 & 3.3544 & 3.348 & $(002)$ & 27 \\
$\mathrm{Cd}_{0.91} \mathrm{Al}_{0.09} \mathrm{~S}$ & 30.98 & 3.3523 & 3.343 & $(002)$ & 28 \\
$\mathrm{Cd}_{0.88} \mathrm{Al}_{0.12} \mathrm{~S}$ & 30.93 & 3.3557 & 3.358 & $(002)$ & 27 \\
$\mathrm{Cd}_{0.88} \mathrm{Al}_{0.18} \mathrm{~S}$ & 30.92 & 3.3596 & 3.369 & $(002)$ & 25 \\
\hline
\end{tabular}

Table 5. Lattice constants, unit cell volume and c/a ratio of $\mathrm{Cd}_{1-\mathrm{x}} \mathrm{Al}_{\mathrm{x}} \mathrm{S}$ system.

\begin{tabular}{ccccc}
\hline \multirow{2}{*}{ Compositions } & \multicolumn{2}{c}{ Lattice constant $(\AA)$} & \multirow{2}{*}{ Volume $(\AA)$} & c/a ratio \\
\cline { 2 - 3 } & $a$ & $c$ & & \\
\hline $\mathrm{Cd}_{1.00} \mathrm{Al}_{0.00} \mathrm{~S}$ & 3.8952 & 6.7405 & 88.566 & 1.730 \\
$\mathrm{Cd}_{0.99} \mathrm{Al}_{0.01} \mathrm{~S}$ & 3.8530 & 6.7209 & 86.405 & 1.744 \\
$\mathrm{Cd}_{0.94} \mathrm{Al}_{0.06} \mathrm{~S}$ & 3.3620 & 6.7146 & 65.725 & 1.997 \\
$\mathrm{Cd}_{0.91} \mathrm{Al}_{0.09} \mathrm{~S}$ & 3.3570 & 6.7062 & 65.448 & 1.997 \\
$\mathrm{Cd}_{0.88} \mathrm{Al}_{0.12} \mathrm{~S}$ & 3.5347 & 6.7092 & 84.324 & 1.739 \\
$\mathrm{Cd}_{0.88} \mathrm{Al}_{0.18} \mathrm{~S}$ & 3.8656 & 6.7322 & 87.118 & 1.741 \\
\hline
\end{tabular}

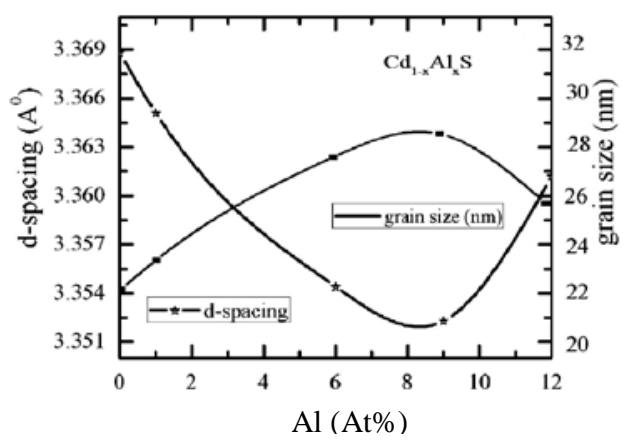

Fig. 4. d-spacing and grain size variation.

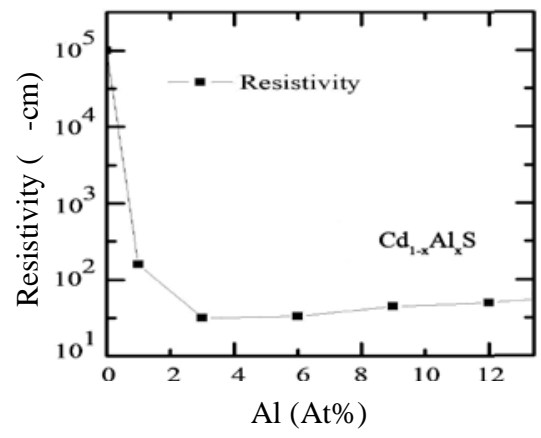

Fig. 5. Resistivity as a function of $\mathrm{Al}$ concentrations. 
The ionic radius of $\mathrm{Al}^{3+}(0.50 \AA)$ is smaller than that of $\mathrm{Cd}^{2+}(0.97 \AA)$, this suggests that at low $\mathrm{Al} \%, \mathrm{Al}^{3+}$ replace $\mathrm{Cd}^{2+}$ in the lattice substitutionally which in turn results in a smaller $\mathrm{d}_{(002)}$ value than that of the un-doped CdS film. As this ratio increases beyond $9 \%$ of $\mathrm{Al}, \mathrm{Al}^{3+}$ start to enter to the lattice both substitutionally and interstitially which caused the $\mathrm{d}_{(002)}$ values to increase again as seen in Fig. 4.

\subsection{Transport properties}

The film resistivity as a function of $\mathrm{Al}$ concentration at $425 \mathrm{~K}$ is shown in Fig. 5. The resistivity is dropped from $1 \times 10^{5} \Omega \mathrm{cm}$ (undoped film) to a minimum of $48 \Omega \mathrm{cm}$ at the ratio of 0.03 and 0.06 , after which it is increased to $98 \Omega \mathrm{cm}$ at the amount of 0.14 . This agrees with the variation of d-value due to $\mathrm{Al}$ concentration. As it is pointed out earlier that, at low concentration, $\mathrm{Al}^{3+}$ ions replace the $\mathrm{Cd}^{2+}$ ions into the lattice substitutionally, this increases the carrier concentration (CC) of the doped film and decreases the resistivity. However, at higher concentrations, $\mathrm{Al}^{3+}$ starts to enter into the lattice sites both substitutionally and interstitially. An interstitial $\mathrm{Al}^{3+}$ ion acts as recombination centers, decreasing the CC and increasing the resisitivity. Such behavior of CC as well as resistivity has also been reported [17-19]. Fig. 6 shows the CC as a function of the Al concentrations. The pure film has a CC of about $3 \times 10^{16} \mathrm{~cm}^{-3}$. The CC increases with the $\mathrm{Al}$ concentrations until it reaches to a maximum $\left(\sim 1.1 \times 10^{19} \mathrm{~cm}^{-3}\right)$ at a concentration of $\mathrm{Al}$ of 0.03 , and then decreases as the concentration of $\mathrm{Al}$ exceeds 0.06 until it drops to $4.8 \times 10^{18} \mathrm{~cm}^{-3}$ at the concentration of $\mathrm{Al}$ of 0.14 .

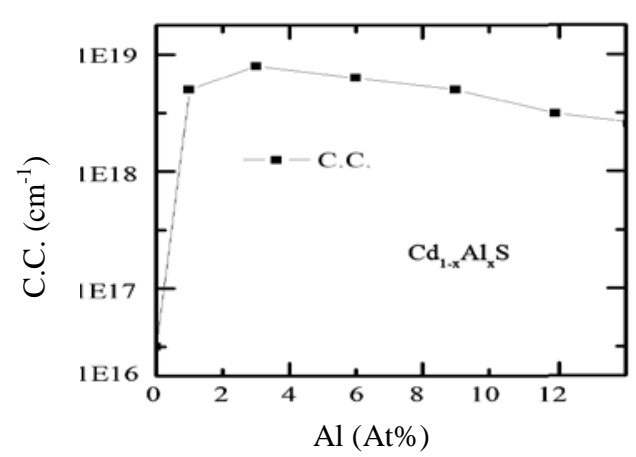

Fig. 6. CC dependence on $\mathrm{Al}$ concentration.

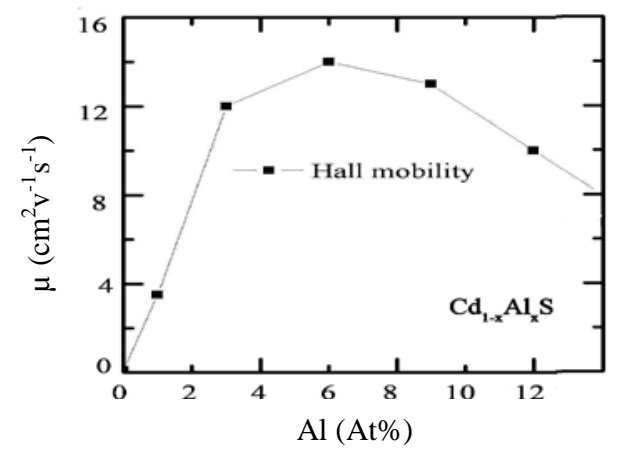

Fig. 7. Variation of Hall mobility with the Al concentration.

Fig. 7 shows the Hall mobility $(\mu)$. The mobility is found to be maximum (14.25 $\mathrm{cm}^{2} \mathrm{v}^{-1} \mathrm{~S}^{-1}$ ) at the concentration of $6 \% \mathrm{Al}$. This value agrees with a similar result reported 
earlier by Bertran et al. [20]. The variation of $\mu$ with respect to the concentration of $\mathrm{Al}$ agrees to some extent with the change of grain size.

\section{Conclusions}

In the present work, Al-doped CdS (viz. $\mathrm{Cd}_{1-\mathrm{x}} \mathrm{Al}_{\mathrm{x}} \mathrm{S}$ ) thin films were prepared by spray pyrolysis method. The SEM micrographs show that films are uniform, smooth and compact. It is also observed that $\mathrm{Al}$ doping has no significant effect on the surface morphology of the CdS thin film. From EDX analysis it is observed that the deposited films are stoichiometric. The grain size is found to be in the range of 22.23 to $28.93 \mathrm{~nm}$. Grain size is decreased at lower concentration of $\mathrm{Al}$ and increased at higher concentration. The XRD and SEM results indicate that the composite films are polycrystalline in hexagonal structure. Their crystallinity decreases with increasing the Al concentration. Hall mobility and carrier concentration are increased in the CdS films with increasing $\mathrm{Al}$ concentration.

\section{Acknowledgements}

The authors are thankful to the Materials Science Division, AECD for providing data of SEM and EDX, Department of Physics \& Engineering Physics, University of Saskatchewan, Canada, for XRD, Department of Applied Physics \& Electronics Engineering, University of Rajshahi, for Electrical measurements.

\section{References}

1. G. E. Delgado, J. E. Contreras, A. J. Mora, L. Bé ancourt, P. Grima-Gallardo, M. Quintero, Chalcogenide Letters, 6 (12), 647 (2009).

2. H. Chavez, M. Jorden, J. C. McClure, G. Lush, V. P. Singh, J. Mat. Sci.: Mater. Electron. 8, 151. (1997). http://dx.doi.org/10.1023/A:1018537928315

3. C. S. Ferekides, D. Marinskiy, S. Marinskaya, B. Tetali, D. Oman, D. L. Morel, IEEE: 25th PVSC, 751 (1996).

4. K. Anuar, Z. Zulkarnain, N. Saravanan, M. Nazri and R. Sharin, Materials Science, 11, 101 (2005).

5. B. Su and K.L. Choy, Thin Solid Films 359, 102 (2000). http://dx.doi.org/10.1016/S0040-6090(99)00857-3

6. A. Ashour, N. El-Kadry and S.A. Mahmoud, Thin Solid Films 269, 117 (1995). http://dx.doi.org/10.1016/0040-6090(95)06868-6

7. S. A. Mahmoud, A. A. Ibrahim and A. S. Riad, Thin Solid Films 372, 144 (2000). http://dx.doi.org/10.1016/S0040-6090(00)01053-1

8. A.I. Oliva, O. Solis-Canto, R. Castro-Rodriguez and P. Quintana, Thin Solid Films 391, 28 (2001). http://dx.doi.org/10.1016/S0040-6090(01)00830-6

9. Ph. Hofmann, K. Horn, A.M. Bradshaw, R.L. Johnson, D. Fuchs and M. Cardona, Phys. Rev. B 47, 139 (1993). http://dx.doi.org/10.1103/PhysRevB.47.1639

10. I. K. Battisha, H.H. Afify, G. Abd El-Fattah and Y. Badr, Fizika A 11, 31 (2002).

11. A. Ashour, H. H. Afify and S. A. Mahmoud, Thin Solid Films 248, 253 (1994). http://dx.doi.org/10.1016/0040-6090(94)90020-5

12. B. Thangaraju, Thin Solid Films 402, 71 (2002). 
http://dx.doi.org/10.1016/S0040-6090(01)01667-4

13. L. J. Van der Pauw, Philips Res. Rep. 13, 1 (1958).

14. J. Dona and J. Herrero, J. Electrochem. Soc. 139, 2810 (1992). http://dx.doi.org/10.1149/1.2068984

15. H. Metin and R. Esen, Semicond. Sci. Technol., 18, 647 (2003). http://dx.doi.org/10.1088/0268-1242/18/7/308

16. M. Rami, E. Benamar, M. Fahoume, F. Chraibi and A. Ennaoui, Solid State Sci. 1, 179 (1999). http://dx.doi.org/10.1016/S1293-2558(00)80073-4

17. M. Nagao and S. Watanabe Japan. J. Appl. Phys. 7, 684 (1968). http://dx.doi.org/10.1143/JJAP.7.684

18. T. Nakanishi and K. Ito, Sol. Energy Mater. Sol. Cells 35, 171 (1994). http://dx.doi.org/10.1016/0927-0248(94)90137-6

19. C. Lokhande and S. Pawar, Solid State Commun. 44, 1137 (1982). http://dx.doi.org/10.1016/0038-1098(82)91071-7

20. E. Bertran, J. Morenza, J. Esteve, and J. Codina, J. Phys. D: Appl. Phys. 17, 1679 (1984). http://dx.doi.org/10.1088/0022-3727/17/8/021 